\title{
UPAYA PENINGKATAN HASIL BELAJAR SISWA DALAM MANAJEMEN PEMBELAJARAN IPA DENGAN MENGGUNAKAN MODEL PEMBELAJARAN KOOPERATIF TEAM ASSISTED INDIVIDUALIZATION (TAI)
}

\author{
Weny Noorhaeny \\ Pascasarjana IAIN Syekh Nurjati Cirebon \\ noorhaeny11@gmail.com
}

\begin{abstract}
This study aims to determine whether the implementation of the TAI learning model can increase the activity and learning outcomes of class VII A students of SMP LabSchool UNESA on the subject matter of Science.This research uses classroom action research. From the results of interviews with subject teachers and direct observation in class VII A, it can be seen that the methods used by science subject teachers have not fully promoted active learning and there tends to be a single communication. The direction in which students tend to be passive in learning. This can be seen from the readiness and activities during the learning process. It can also be seen from the learning outcomes that have not been optimal, meaning that they have not reached the specified minimum completeness criteria (KKM), namely 70. In this study, the researcher used one class to apply the Team Assisted Individualization (TAI) learning model, namely class VII A, which has 19 students. The results of research conducted by researchers prove that there is an increase in the activity and learning outcomes of students in participating in learning with the implementation of the Team Assisted Individualization (TAI) learning model. The results of this study are expected to provide knowledge to all parties (students, teachers, parents) to be able to increase the activities and learning outcomes of students in science subjects.
\end{abstract}

Keywords : Team Assisted Individualization, learning model

\begin{abstract}
Abstrak
Penelitian ini bertujuan untuk mengetahui apakah implementasi model pembelajaran TAI dapat meningkatkan aktivitas dan hasil belajar peserta didik kelas VII A SMP LabSchool UNESA pada materi pokok IPA.Penelitian ini menggunakan penelitian tindakan kelas (classroom action research. Dari hasil wawancara dengan guru mata pelajaran dan observasi secara langsung di kelas VII A dapat diketahui bahwa metode yang digunakan oleh guru bidang studi mata pelajaran IPA belum secara penuh mengedepankan pembelajaran aktif dan cenderung terjadi komunikasi satu arah dimana peserta didik cenderung pasif dalam pembelajaranHal ini dapat dilihat dari kesiapan dan aktivitas pada saat pembelajaran berlangsung, juga tampak dari hasil belajar yang belum optimal artinya belum mencapai Kriteria Ketuntasan Minimal (KKM) yang ditetapkan yaitu 70. Dalam penelitian ini, peneliti menggunakan satu kelas untuk menerapkan model pembelajaran Team Assisted Individualization (TAI) yaitu kelas VII A yang jumlahnya ada 19 peserta didik.Hasil penelitian yang dilakukan oleh peneliti membuktikan bahwa ada peningkatan aktivitas dan hasil belajar peserta didik dalam mengikuti pembelajaran dengan implementasi model pembelajaran Team Assisted Individualization (TAI). Hasil penelitian tersebut diharapkan dapat memberikan pengetahuan kepada semua pihak (peserta didik, guru, orang tua) untuk dapat meningkatkan aktivitas dan hasil belajar peserta didik pada mata pelajaran IPA.
\end{abstract}

Kata Kunci: Team Assisted Individualization, model pembelajaran

Upaya Peningkatan Hasil Belajar Siswa dalam Manajemen Pembelajaran IPA dengan Menggunakan Model Pembelajaran Kooperatif Team Assisted Individualization (TAI) 


\section{PENDAHULUAN}

Pendidikan merupakan usaha untuk mengembangkan dan membina potensi sumber daya manusia melalui berbagai kegiatan belajar mengajar yang diselenggarakan pada semua jenjang pendidikan dari tingkat dasar, menengah, dan perguruan tinggi. Pendidikan di sekolah mempunyai tujuan untuk mengubah siswa agar dapat memiliki pengetahuan, ketrampilan, dan sikap belajar sebagai bentuk perubahan perilaku belajar, sehingga tujuan pendidikan dapat tercapai.

Pendidikan Ilmu Pengetahuan Alam (IPA) sebagai bagian dari pendidikan pada umumnya memiliki peran penting dalam peningkatan mutu penelitian khususnya didalam menghasilkan peserta didik yang berkualitas yaitu manusia berfikir kritis, kreatif, logis dan berinisiatif dalam menangapi isu di masyarakat yang diakibatkan oleh dampak perkembangan Ilmu Pengetahuan Alam (IPA) dan Teknologi.

Guru merupakan bagian yang tidak dapat dipisahkan dari sistem pendidikan secara keseluruhan yang terlibat langsung dalam proses belajar mengajar. Gurulah yang berperan langsung dalam mengajar dan mendidik murid-muridnyaGuru merupakan ujung tombak dari tercapainya tujuan pembelajaran yang ditargetkan. Proses pembelajaran adalah sesuatu yang memegang peranan penting dalam peningkatan kualitas sumber daya manusia. Proses pembelajaran itu sendiri merupakan tugas pokok guru dengan sasaran untu pembelajaran siswa. Dalam proses pembelajaran yang berlangsung selama ini, siswa cenderung pada pola belajar menghafal yang mengakibatkan siswa sulit memahami pelajaran, sehingga menjadikan pembelajaran kurang bermakna.

Dewasa ini, pembelajaran masih didominasi oleh pengunaan metode ceramah dan kegiatannya lebih berpusat pada guru. Aktifitas siswa dapat dikatakan hanya mendengarkan penjelasan guru dan mencatat hal-hal yang diangap penting.

SMP Labschool UNESA Surabaya masih menggunakan pola lama, yaitu guru masih sangat dominan dalam proses pembelajaran. Hal ini menyebabkan siswa lebih bersifat pasif dan cenderung hanya menunggu informasi dari pada mencari dan menemukan sendiri pengetahuan, ketrampilan dan sikap yang mereka butuhkan. Selain itu guru kurang memperhatikan kemampuan berfikir siswa sehingga motivasi belajar siswa menjadi sulit dibangkitkan. Sedangkan untuk belajar mata pelajaran IPA tidak cukup dengan menghafalkan materi yang diberikan oleh guru, tetapi siswa dituntut mampu memahami materi dan menerapkannya serta menghubungkan teori dan kenyataan di lapangan secara kontekstual.
Masalah rendahnya hasil belajar siswa pada mata pelajaran IPA mendapat perhatian khusus bagi para guru yang merupakan komponen utama dalam proses pembelajaran, terutama guru mata pelajaran. Guru perlu menerapkan pendekatan, model, metode dan strategi pembelajaran yang tepat, objektif, dan efesien agar materi yang disampaikan mudah dipahami dan di mengerti.

Di dalam dunia pendidikan, dikenal adanya pembelajaran aktif. Pembelajaran aktif adalah suatu pembelajaran yang dikelola dengan memperbanyak membuka ruang kepada siswa untuk lebih kreatif dan aktif sehingga tercipta suasana belajar yang sesuai dengan konsep dan makna melalui berbagai kegiatan yang didukung oleh berbagai informasi dan sumber belajar berdasarkan potensi dan karakteristik yang mereka miliki. Kegiatan-kegiatan yang dilaksanakan oleh peserta didik diarahkan untuk menambah pengalaman dan pengetahuan agar memiliki kemampuan analisis dan sintesis.

Berbagai jenis pembelajaran aktif diantaranya: Student Teams Achiement Devisions (STAD), Teams Games Tournament (TGT), Jigsaw, Team Assisted Individualization (TAI) dan Cooperative Integrated Reading and Composition (CIRC) (Robert E. Slaavin 2011:14).

\section{METODE}

Penelitian ini merupakan penelitian tindakan (action research), karena penelitian dilakukan untuk memecahkan masalah pembelajaran di kelas. Penelitian ini termasuk penelitian deskriptif, sebab mengambarkan bagaimana suatu teknik pembelajaran diterapkan dan bagaimana hasil yang diinginkan dapat dicapai.

Penelitian ini digunakan untuk mengkaji permasalahan dan memperoleh makna tentang Upaya Peningkatan Siswa dalam Manajemen Pembelajaran Dengan Menggunakan Model pembelajaran Kooperatif Team Assisted Individualization (TAI) di SMP LabSchool UNESA Surabaya.

Untuk kepentingan tersebut ditempuh langkah-langkah sebagai berikut:

1. Memilih lokasi penelitian. Sesuai dengan masalah penelitian yaitu di SMP LabSchool UNESA Surabaya sebagai lokasi penelitian ini.

2. Penelitian ini hanya dilakukan di satu sekolah saja yaitu di SMP LabSchool UNESA Surabaya

3. Setelah Peneliti menetapkan lokasi penelitian, peneliti bertemu dengan kepala

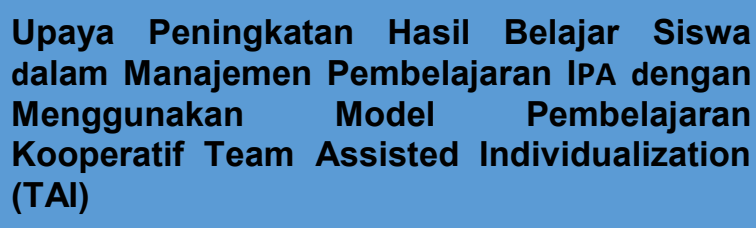


sekolah dan guru yang sebelumnya sudah mengadakan hubungan

4. Peneliti mencatat apa yang akan dilakukan di tempat lokasi berdasarhan hasil dokumen, observasi dan wawancara.

Menurut Sudikin dkk (2002:54) ada 4 macam bentuk penelitian tindakan, yaitu:

1. Penelitian tindakan guru sebagai peneliti

2. Penelitian tindakan kolaborasi.

3. Penelitian tindakan simultan terintegratif.

4. Penelitian tindakan sosial eksperimental.

Dalam penelitian ini mengguna-kan bentuk penelitian tindakan kolaborasi, dimana peneliti bekerja sama dengan kepala sekolah dan guru kelas. Tujuan utama penelitian tindakan kelas ialah untuk meningkatkan praktik-praktik pembelajaran di kelas.

Penelitian yang dilaksanakan termasuk penelitian tindakan kelas (classroom action research). Penelitian tindakan kelas adalah penelitian yang dilakukan oleh guru di kelasnya sendiri melalui refleksi diri dengan tujuan untuk memperbaiki kinerjanya sehingga hasil belajar peserta didik meningkat (Zainal Aqib 2008:3). Penelitian ini terdiri dari dua siklus dan di awali dengan pra siklus. Setiap siklus terdiri dari empat aspek, yakni perencanaan, pelaksanaan tindakan, pengamatan, dan refleksi.

\section{Teknik Pengumpulan Data}

a. Metode Wawancara

"Wawancara adalah merupakan pertemuan dua orang untuk bertukar informasi dan ide melalui tanya jawab, sehingga dapat dikontruksikan makna dalam suatu topik tertentu" (Sugiono 2008:72). Metode wawancara digunakan untuk mengetahui permasalahan-permasalahan dalam pembelajaran.

\section{b. Metode Dokumentasi}

Metode dokumentasi digunakan untuk mendapatkan daftar nama peserta didik dari kelas VII A SMP LabSchool UNESA Surabaya dan nilai peserta didik 2 tahun sebelumnya pada materi pokok Mahluk Hidup dan Mahluk Tidak Hidup (Benda Mati) sebagai nilai pra siklus.

$$
\text { Persentase }(\%)=\frac{\text { Jumlah Skor }}{\text { SMI }} \times 100 \%
$$

Keterangan:

$\mathrm{SMI}=$ skor maksimum ideal .

\section{c. Metode Tes}

Tes digunakan untuk mendapatkan hasil belajar peserta didik setelah melakukan pembelajaran pada materi pokok Mahluk hidup dan Mahluk Tidak Hidup (Benda Mati) dengan model Team Assiated Individualization (TAI), baik pada siklus 1 maupun siklus 2 .

\section{d. Metode Observasi}

Pengamatan dilakukan pada setiap siklus dengan menggunakan instrument pengamatan. Pengamatan siklus I dipakai untuk direfleksikan pada siklus 2. Metode ini dilakukan untuk memperoleh data mengenai pengelolaan pembelajaran dengan model pembelajaran TAI (Team Assisted Individualization) oleh guru dan aktivitas peserta didik serta aktivitas diskusi kelompok.

\section{Rumus Ketuntasan Belajar Individu}

Data hasil belajar individu ditentukan dari penggabungan seluruh hasil pekerjaan peserta didik dengan persentase $25 \%$ untuk lembar kerja, $25 \%$ untuk kuis, dan $50 \%$ untuk tes evaluasi.

Ketuntasan belajar individu:

$$
\text { Nilai Akhir }=\frac{(25 \times \text { Lembar Kerja })+(25 \times \text { Kuis })+(50 \times \text { Evaluasi })}{100}
$$

Peserta didik dikatakan tuntas belajar apabila nilai yang dicapai peserta didik minimal 70 .

\section{Rumus Ketuntasan Belajar klasikal}

Data yang diperoleh dari hasil belajar dapat ditentukan ketuntasan belajar klasikal menggunakan analisis deskriptif persentase dengan perhitungan:

$$
\text { Ketuntasan belajar klasikal }=\frac{\sum \text { Peserta didik yang tuntas belajar }}{\sum \text { Seluruh peserta didik }} \times 100 \%
$$

Perhitungan persentase pengelolaan pembelajaran

\section{HASIL DAN PEMBAHASAN}

Untuk pra siklus peneliti menggunakan nilai tes ulangan harian peserta didik pada materi Mahluk Hidup dan Benda Mati pada 2 tahun pelajaran sebelumnya, yaitu tahun pelajaran 2017/2018 dan 2018/2019. Adapun hasil analisis yang diperoleh adalah sebagai berikut:

Tabel 1. Team Baik mendapatkan hadiah.

\begin{tabular}{|c|c|}
\hline Rata-rata kelas & 64,14 \\
\hline Ketuntasan & $61 \%$ \\
\hline
\end{tabular}


Nilai rata-rata kelas materi Mahluk Hidup dan Benda Mati pada tahun pelajaran 2017/2018 dan 2018/2019 adalah 64,14 dan ini menunjukkan masih di bawah kriteria ketuntasan minimal (KKM) yaitu 65. Untuk aktivitas peserta didik yang tergolong aktif masih sangat rendah yaitu hanya 50\% sedangkan yang lainnya tergolong cukup dan kurang aktif.

Tabel 2. Aktivitas Peserta didik Pada Pra Siklus

\begin{tabular}{|c|c|}
\hline Aktif & $50 \%$ \\
\hline Cukup Aktif & $26 \%$ \\
\hline Kurang aktif & $24 \%$ \\
\hline
\end{tabular}

Pada pelaksanaan siklus I ada beberapa kekurangan yang dapat dilihat dari belum aktifnya peserta didik karena belum mengetahui secara benar langkah-langkah pelaksanaan model pembelajaran Team Assiated Individualization (TAI), sehingga peserta didik kurang memahami tanggung jawab tim. Pada siklus I peserta didik yang termasuk kriteria sangat aktif ada $11 \%$, aktif $57 \%$ dan cukup aktif 32\% sehingga belum mencapai indikator keberhasilan dalam penelitian ini. Aspek- aspek yang dinilai sebagai aktivitas peserta didik adalah antusias peserta didik dalam mengikuti KBM, kelancaran mengemukakan ide dalam memecahkan masalah, keaktifan peserta didik dalam belajar individu, keaktifan peserta didik dalam diskusi, keaktifan menanggapi pertanyaan dari guru, keaktifan menanggapi pertanyaan dari teman, keaktifan dalam bertanya, keaktifan peserta didik dalam mencari sumber belajar, dan kelancaran peserta didik dalam menjawab pertanyaan. Rata-rata hasil belajar peserta didik pada siklus I telah mencapai 76,31 dan itu menunjukkan sudah memenuhi KKM yang ditetapkan yaitu 70 tetapi ketuntasan klasikal terpenuhi karena peserta didik yang tuntas hanya $64 \%$. Karena siklus I belum mencapai indikator yang ditetapkan baik aktivitas maupun hasil belajar peserta didik maka perlu adanya siklus II sebagai perbaikan.

Untuk perbaikan siklus II terjadi perubahan kelompok dengan mempertimbangkan nilai yang diperoleh peserta didik pada siklus I dari nilai lembar kerja, kuis dan evaluasi. Persentase aktivitas peserta didik yang dicapai pada siklus II yaitu $57 \%$ mencapai kriteria sangat aktif, 32\% mencapai kriteria aktif dan $11 \%$ mencapai kriteria cukup aktif. Rata-rata hasil belajar yang diperoleh adalah 77,77 dengan ketuntasan klasikal $89 \%$. Pada siklus II aktivitas dan hasil belajar peserta didik telah mencapai indikator keberhasilan yaitu sekurangkurangnya ada $75 \%$ peserta didik yang mencapai kriteria aktif dan ketuntasan klasikal peserta didik yang memenuhi KKM ada $75 \%$ maka tidak perlu diadakan siklus berikutnya.

Berikut perkembangan aktivitas peserta didik dari pra siklus, siklus I dan siklus II. 
Tabel 3. Aktivitas Peserta Didik.

\begin{tabular}{|c|c|c|c|c|}
\hline \multirow{2}{*}{ Siklus } & \multicolumn{4}{|c|}{ Kategori } \\
\cline { 2 - 5 } & Sangat Aktif & Aktif & Cukup Aktif & Kurang aktif \\
\hline Pra & - & $50 \%$ & $26 \%$ & $24 \%$ \\
\hline I & $11 \%$ & $57 \%$ & $32 \%$ & - \\
\hline II & $57 \%$ & $32 \%$ & $11 \%$ & - \\
\hline
\end{tabular}

Pada siklus I aktivitas peserta didik yang termasuk kategori aktif dan sangat aktif baru $68 \%$ dan siklus II mengalami peningkatan sehingga mencapai $89 \%$. Pada siklus II ini aktivitas peserta didik telah mencapai indikator dalam penelitian ini.

Adapun hasil belajar dalam penelitian ini menggunakan proporsi $25 \%$ untuk nilai lembar kerja, 25\% untuk nilai kuis, dan 50\% untuk tes evaluasi. Adapun perkembangan hasil belajar dari siklus I dan siklus II dapat dilihat pada tabel berikut.

Tabel 4. Perkembangan Hasil Belajar Peserta Didik

\begin{tabular}{|c|c|c|c|}
\hline \multirow{2}{*}{ Siklus } & \multirow{2}{*}{ Rata-rata } & \multicolumn{2}{|c|}{ Ketuntasan } \\
\cline { 3 - 4 } & & Tuntas & Tidak Tuntas \\
\hline Pra & 64,14 & $61 \%$ & $39 \%$ \\
\hline I & 76,31 & $64 \%$ & $36 \%$ \\
\hline II & 77,77 & $89 \%$ & $11 \%$ \\
\hline
\end{tabular}

Pada siklus I nilai rata-rata telah memenuhi indikator yaitu 76,31 padahal indikator yang ditetapkan adalah 70, tetapi ketuntasan klasikal masih di bawah indikator yang ditetapkan yaitu $64 \%$ padahal indikator yang ditetapkan adalah $75 \%$ sehingga perlu diadakan siklus II. Pada siklus II indikator dalam penelitian ini telah tercapai yaitu dengan rata-rata kelas 77,77 dan ketuntasan klasikal $89 \%$. Berikut histogram perkembangan persentase aktivitas peserta didik dari pra siklus, siklus I sampai siklus II.
Gambar 2. Histogram Perkembangan Persentase Aktivitas Peserta Didik

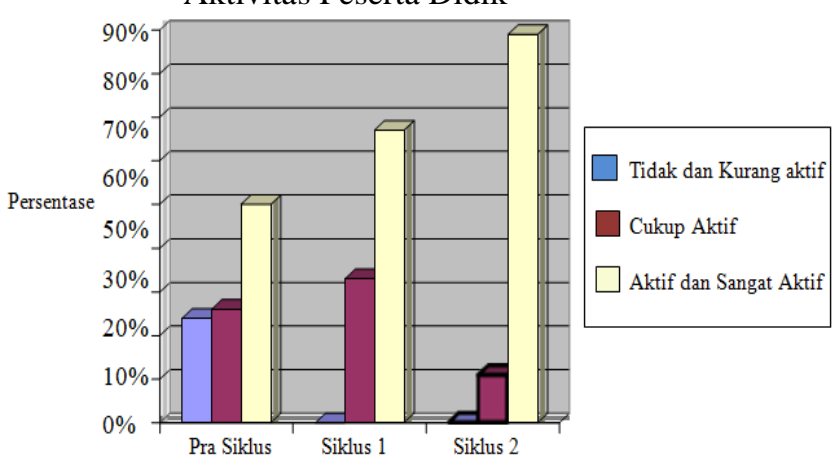

Berikut histogram perkembangan rata-rata hasil belajar dari pra siklus, siklus I sampai siklus II.

Gambar 3. Histogram Perkembangan Rata-Rata Hasil Belajar

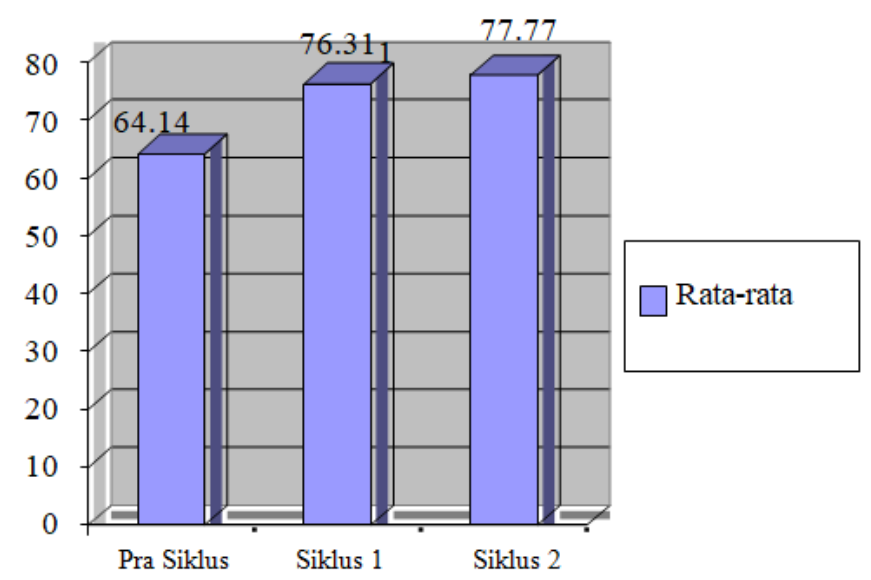

\section{KESIMPULAN}

Berdasarkan penelitian tindakan kelas yang telah dilaksanakan dan deskripsi data serta analisis penelitian tentang implementasi model pembelajaran Team Assisted Individualization (TAI) untuk meningkatkan hasil belajar peserta didik pada materi pokok Mahluk Hidup dan Mahluk Tidak Hidup (Benda Mati) semester ganjil kelas VII A SMP LabSchool UNESA Surabaya tahun pelajaran 2019/2020 dari bab I sampai bab IV maka pada akhir tesis ini dapat diambil simpulan sebagai berikut.

Melalui implementasi model pembelajaran TAI dapat meningkatkan aktivitas belajar peserta didik kelas VII A SMP LabSchool UNESA Surabaya pada tahun pelajaran 2019/2020. Pada pra siklus peserta didik yang mencapai kriteria aktif baru $50 \%$, siklus I mencapai $67 \%$ dan siklus II meningkat menjadi $89 \%$.

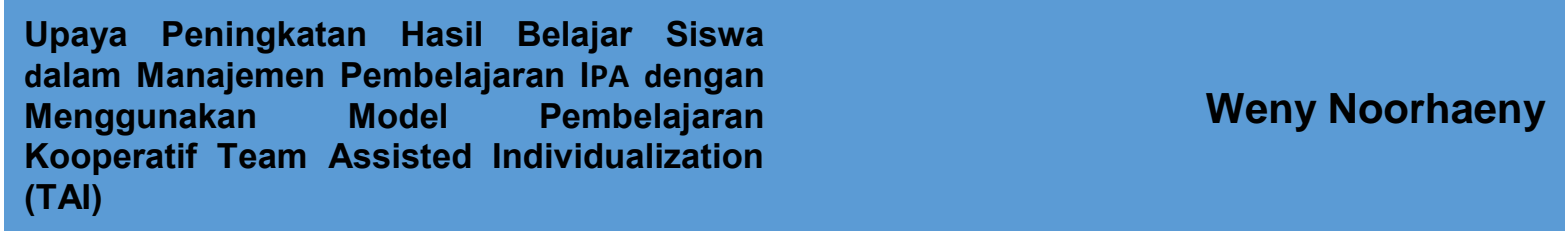


Melalui implementasi model pembelajaran TAI dapat meningkatkan hasil belajar peserta didik kelas A pada materi IPA tahun pelajaran 2019/2020. Pra siklus nilai rata-rata yang diperoleh peserta didik masih 63, 9 dengan ketuntasan klasikal 62,5\%, siklus I meningkat dengan rata-rata 76,31 dengan ketuntasan klasikal $64 \%$ dan siklus II juga meningkat menjadi 77,77 untuk nilai rata-rata dengan ketuntasan klasikal yang dicapai adalah $89 \%$.

\begin{tabular}{lrr}
\multicolumn{2}{r}{ Setelah peneliti mengetahui manfaat dari } \\
model pembelajaran & Team & Assisted \\
Individualization (TAI), & maka peneliti
\end{tabular} mengemukakan saran yang dapat dipertimbangkan:

Penggunaan model pembelajaran Team Assisted Individualization (TAI), sebagai salah satu bentuk variasi dalam pembelajaran IPA. Guru lebih kreatif dan berani mencoba dalam menerapkan model pembelajaran yang lain selain yang digunakan sehari-hari. Salah satunya dengan menerapkan model pembelajaran kooperatif.

\section{DAFTAR PUSTAKA}

Aqib, Zainal dkk, Penelitian Tindakan Kelas, Bandung: Yrama Widya, 2008.

Arikunto, Suharsimi, Prosedur Penelitian Suatu Pendekatan Praktik, Edisi Revisi VI, Jakarta: PT Rineka Cipta, 2006, Cet. 16.

Fathurrohman, Model-model Pembelajaran Inovatif, Yojakarta: Ar Ruz Media, 2015.

Pidarta, Made; Manajemen Pendidikan, Rineka Cipta, Jakarta 2011

Slavin, Robert E, Cooperative Learning : Theory, Research, and Practice, London: Allym and Bacon, 1995.

Slavin, Robert E, Cooperative Learning: Teori, Riset dan Praktik, terj. Nurulita Yusron, Bandung: Nusa Media, 2008.

Suharsini Arikunto, suhardjono, Penelitian Tindakan Kelas, Jakarta, Bumi Aksara 2008.

Sugiyono, Memahami Penelitian Kualitatif, Jakarta: CV Alfabeta, 2008.

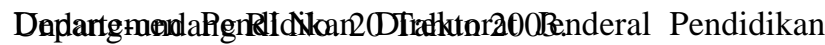
dasar dan Menengah, Penelitian Tindakan Kelas, Jakarta : Direktorat Tenaga Kependidikan, 2003.
Syah, Muhibbin, Psikologi Pendidikan Suatu Pendekatan Baru, Bandung: PT Remaja Rosdakarya, 1995.

Yamin, Martinis, Mengembangkan Kompetensi Pembelajar, Jakarta: UI Press, 2004.

Zuriah, Nurul, Metodologi Penelitian Sosial dan Pendidikan: Teori dan Aplikasi, Jakarta: Bumi Aksara, 2006. 